\title{
Assessing the Financial Performance of Investment Banks in Pakistan During the Current Financial Crisis
}

\author{
Mirza Asjad Baig, ${ }^{*}$ Muhammad Ali Usman, ${ }^{* *}$ Mirza Owais \\ Baig $^{* * *}$
}

\begin{abstract}
Investment banks play a vital role in the economic development of a country through their impact on capital and money markets. In developing countries, they promote and support business investors in bringing about economic stability. The investment banking industry faced significant challenges as a result of the financial crisis in 2008. This study presents a detailed financial analysis of the recent performance of seven investment banks in Pakistan for the period 2007-11 with the help of financial ratios. The banks were assessed across several perspectives: profitability, efficiency, liquidity, leverage, and other financial measures such as institution size. Our findings show that all banks faced a significant squeeze on profitability, although the smaller banks performed better overall. This implies that successful performance does not necessarily depend on economies of scale.
\end{abstract}

Keywords: Investment banks, financial ratios, financial crisis, economic instability.

JEL classification: G32, G01, O16, G24.

\section{Introduction}

The banking sector plays a vital role in the development and welfare of a society, and are especially important for a healthy economy among developed countries. During the $18^{\text {th }}$ century, industries expanded their business and trading activities with the beginning of large-scale production. The banking industry became important in promoting business operations as an essential facility. In today's global market, it is necessary for the banking sector to provide quality products/services and focus on customer satisfaction to augment its performance. Financial systems are important for sustainable economic development as they facilitate the mobilization of

\footnotetext{
${ }^{*}$ The author is based at the Economics Department, Institute of Business Management, Karachi.

** The author is based at the Finance Department at Middlesex University in the UK.

${ }^{* * *}$ The author is based at the Finance Department at GBC, Karachi.
} 
funds. Today's uncertain economic (micro and macro) environment requires effective and efficient financial systems for production and a competitive market to help economic transactions and retain a healthy relationship with investors. The allocation of resources becomes possible through the availability of an efficient and stable financial system, which improves the financial performance of organizations.

Pakistan's investment banking sector developed in the 1980s. Realizing the need for investment banking services, policymakers issued a charter for investment banks that visualized a wide range of business services, including capital and money market activities, corporate financial services, project financing, and money market operations. These banks performed well and continued to flourish till the mid-1990s, their growth bolstered by favorable economic conditions, the stock market boom, and broad-ranging financial liberalization measures.

Investments banks play a key role in capital formation, which is vital for breaking the vicious circle of poverty. They help government and corporate agencies raise funds by selling and issuing securities in a primary market; they also help private and public investors create wealth when investing in the capital market. Recently, the services provided by commercial and investment banks have begun to overlap. Greater competition within the banking sector has meant that investment banks are less able to generate fees and interest income from the advisory and financing services they provide. Our aim is to conduct a detailed financial analysis of the recent performance of investment banks in Pakistan during the global economic recession. The study has the following objectives:

- To identify which bank-specific factors affect the efficiency and performance of investment banks in the literature

- To evaluate their performance across several financial perspectives, such as profitability, efficiency, liquidity, and leverage.

\section{Literature Review}

Athanasoglou, Delis, and Staikouras (2006) have conducted a panel study on the profitability of credit institutions in southeastern Europe for the period 1988-2002. They find that bank-specific internal factors such as loans, assets, deposits, equity, capital ratio, credit risk, productivity growth, and size significantly affect a bank's profitability. However, the authors do not establish a positive or direct link between profitability and banking 
reforms although some macroeconomic determinants, such as the economic and legal environment, do indicate mixed effects.

Amor-Tapia, Tascón, and Fanjul (2006) examine banking efficiency for a sample drawn from the Organization for Economic Co-operation and Development (OECD). They find that the profitability of commercial banks in the OECD countries depends on a higher leverage ratio. Thus, profitability improves with a lower overheads ratio by reducing the type of costs, which is generally considered to signal efficiency.

Vong and Chan (2006) examine the impact of internal and external banking determinants on Macao's banking industry over a 15-year period. Their results suggest that only highly capitalized banks are associated with low-risk high profitability. Larger banking networks also tend to be more profitable than smaller ones. Bank profitability is influenced by loan-loss provisions as well. Athanasoglou, Brissimis, and Delis (2008) carry out an empirical study to determine the impact of bank- and industry-related macroeconomic factors on the profitability of Greek banks. Their outcomes reveal that the equity-to-asset ratio is an important indicator in explaining bank profitability, while high credit risk can cause a decline in profit.

Abreu and Mendes (2002) consider the interest margins and profitability of different European banks for the period 1986-99. They conclude that highly capitalized banks have higher interest margins and lower bankruptcy costs. Al-Hashimi (2007) studies net interest rate margins for banks across 10 sub-Saharan African countries and finds that deviations across the region are explained by credit risk and insufficient operational practices. Macroeconomic risks, however, have a limited effect on net interest rate margins.

Naceur (2003) analyzes the determinants of profitability for the Tunisian banking sector over the period 1980-2000. The study emphasizes the correlation between profitability and high net interest margins and their association with large volumes of capital and large banking overheads. Loans and bank size have a positive and negative impact, respectively, on profitability. However, Hassan and Bashir (2003) and Staikouras and Wood (2003) find that higher loan ratios have a negative impact on profits.

Berger and Humphrey (1997) examine more than 100 studies on 21 different countries that apply frontier efficiency analysis to financial institutions. They find that the per-unit costs of labor and physical capital 
are significantly correlated while natural differences exist in banks' operational efficiency across Asian countries. Kwan (2003) reports that a small number of banks dominate the industry in Asian countries, which is why researchers tend to rely on fewer observations and study the banking efficiency of a specific country. The operating costs of Asian banks declined over 1992-97, which, in turn, improved their operating performance.

Bourke (1989) and Molyneux and Thornton (1992) associate better quality management with profitability as well as with external factors such as the interest rate, inflation, and cyclical output, and on market characteristics such as ownership size and industry size.

The performance of an organization depends on certain factors such as market share, cost reduction, and profitability. Financial indicators that reflect performance include earnings per share (EPS), return on investment (ROI), return on equity (ROE), operating cash flows, and return on invested capital. Corporations measure their performance based on these markers (Sørensen, 2002). Rashid, Sambasivan, and Johari (2003) evaluate the financial performance of corporations based on the current ratio, ROI, and return on assets (ROA), and find that it has increased in the last few years. Ho and $\mathrm{Wu}(2006)$ use firms' financial statements to study a range of financial ratios, including profitability, liquidity, leverage, asset utilization, and growth.

Khawaja and Din (2007) use cross-sectional data to examine the factors determining interest spread in Pakistan's banking sector. They apply generalized least squares to various factors such as market share, equity, nonperforming loans, liquidity, administrative costs, interest rates, GDP growth, and inflation. The study does not find any evidence that interest spread affects the performance of the banking industry.

Raza, Farhan, and Akram (2011) observe that effective and efficient operations are a key element in assessing firm performance as they have a direct impact on survival. They classify investment banks in Pakistan based on their financial ratios over the period 2006-09. Rehman and Raoof (2010) assess a sample of public, private, and foreign banks for the period 19982007, based on data envelopment analysis, and conclude that the efficiency of Pakistan's banking sector matches that of global banks. Akhtar (2002) has carried out a similar study, using deposits and capital as inputs and investment portfolios, loans, and advances as outputs. 
Rizvi (2001) studies the productivity of the banking sector in Pakistan over the period 1993-98. Using data envelopment analysis, he determines the efficiency of the sector and finds that its total factor productivity is exhausted. However, domestic banks appear to operate better than foreign banks. Ataullah, Cockerill, and Le (2004) carry out a comparative analysis of commercial banks in Pakistan and India for the period 1988-98. They find that efficiency scores in an income-based model are much lower than in a loan-based model and suggest that both countries' banking systems still have ample room for improving their efficiency levels.

Burki and Niazi (2003) examine the impact of financial reforms on the efficiency of state-owned, private, and foreign banks in Pakistan, using data on 40 banks for the period 1991-2000. They suggest that factors such as bank size, the ration of interest income to earning assets, and the loansto-deposits ratio have a positive impact on efficiency.

Using ANOVA, Tukey's HSD test, and Levene's test, Ali, Yahya, Nauman, Raza, and Gilani (2012) determine whether investment banks in Pakistan earned a profit during the period 2001-11. The study employs financial indicators such as equity, paid-up capital, total shares, taxation, total assets, and profitability. The authors conclude that investment banks have played a vital role in enhancing economic activity in Pakistan. Rehman, Fatima, and Ahmad (2011) explore the relationship between variables such as economic growth, lending, savings, inflation, the real interest rate, and deposits for the period 1973-2008. Applying regression analysis, they conclude that financial reforms have had a positive impact on Pakistan's economic growth.

Gul, Irshad, and Zaman (2011) examine the relationship between bank-specific and economic indicators, using data for the period 2005-09. Employing pooled ordinary least squares, they present strong evidence that both internal and external factors (loans, assets, deposits, equity, economic growth, inflation) affect profitability (ROA, ROE, net interest margins, and return on capital employed [ROCE]) in Pakistan. Aurangzeb (2012) applies ordinary least squares to data on deposits, investment, advances, profitability, and interest earnings for 1981-2010, and concludes that all these variables have a positive and significant impact on economic growth.

Akmal and Saleem (2008) investigate banking efficiency in Pakistan for the period 1996-2005, based on a sample of 30 commercial banks (stateowned, foreign, and private). Applying a two-stage data envelopment 
analysis, they find that, in the last 10 years, total productivity has grown by only 5 percent as against the large growth in technology; this is very low compared to other sectors of the economy. Nasir and Khalid (2004) analyze patterns of investment and savings, applying ordinary least squares to data for 1971-2003. They show that government expenditure, the GDP growth rate, and growth in remittances have a positive and significant impact on national savings.

\section{Methodology}

The study's methodology uses financial ratios to examine the average efficiency and performance of investment banks in Pakistan. Much of the literature has looked at several aspects of banking, such as operations, financing products, efficiency, and financial performance (see, for example, Short, 1979; Bourke, 1989; Molyneux \& Thornton, 1992; Demirgüç-Kunt \& Huizinga, 2000; Bikker \& Hu, 2002; Berger \& Humphrey, 1997; Barajas, Steiner, \& Salazar, 1999).

Currently, 20 investment banks (see Appendix) operate in Pakistan; of these, nine are listed on the Karachi Stock Exchange. We have selected seven ${ }^{1}$ of the nine listed ${ }^{2}$ investment banks based on size and public availability of data. Accordingly 35 percent of the total population is taken as a sample (i.e., seven banks out of 20).

This study is based on a secondary dataset that covers a five-year period from 2007 to 2011 for a sample of seven investment banks. The data were taken from the annual reports/financial statements of the individual banks and used to compute a range of financial ratios that reflect profitability, liquidity, leverage, and financial efficiency. These are, in turn, used to analyze the average financial performance of the sample banks during the financial crisis from 2007 to 2011. Following Ali et al. (2012), we use ROE, ROA, EPS, ROCE, the current ratio, capital ratio, total equity, and total assets; additionally, we employ the debt-to-asset, debt-to-equity, and asset turnover ratios and net profitability.

\footnotetext{
${ }^{1}$ Security Investment Bank, Trust Investment Bank, First Dawood Investment Bank, First Credit Investment Bank, Escorts Investment Bank Ltd, IGI Investment Bank Ltd, and Invest Capital Investment Bank Ltd.

${ }^{2}$ http://www.kse.com.pk/
} 


\section{Results}

Table 1 compares the average financial ratios of the seven listed investment banks over 2007-11. In terms of average total assets, the top four banks are IGI, First Dawood, Trust Investment Bank, and Invest Capital. During 2007-11, all seven banks' performance was greatly affected by the global financial crisis. The three smaller banks-First Credit, Escorts, and Security-suffered smaller losses than the other larger banks. Based on average operating profit, Invest Capital performed best while First Dawood fared the worst.

All seven banks' average ROA (profitability ratio) follows a negative trend due to fluctuations in their main business operations. First Capital and First Dawood have a higher ROA than the other investment banks. First Credit (a small bank) has a higher average ROE than the larger banks; small banks appear to handle their expenditure more efficiently than larger banks. The declining trend in net income affects EPS, indicating that small banks' EPS is higher than that of larger banks. Larger banks have a better average operating profit margin, suggesting that the higher the margin, the better will be the bank's performance.

The asset turnover ratio (financial efficiency) follows a positive trend for all seven investment banks, but the smaller banks have a higher level of financial efficiency and also maintain a reasonable average current ratio (liquidity ratio) throughout the period. All the investment banks were able to meet their financial obligations to creditors. The average capital ratio (leverage ratio) of the smaller banks suggests that they were financially more stable over the five-year period. The leverage ratio indicates that Trust (a large bank) and Security (a small bank) financed their equity and assets ratio largely using their total liabilities. 
Table 1: Indicators for investment banks (average value for 2007-11)

\begin{tabular}{|c|c|c|c|c|c|c|c|}
\hline $\begin{array}{l}\text { Financial } \\
\text { ratio }\end{array}$ & IGI & $\begin{array}{c}\text { First } \\
\text { Dawood }\end{array}$ & Trust & $\begin{array}{l}\text { Invest } \\
\text { Capital }\end{array}$ & Escorts & $\begin{array}{l}\text { First } \\
\text { Credit }\end{array}$ & Security \\
\hline $\begin{array}{l}\text { Total equity } \\
\text { (PRs mn) }\end{array}$ & $1,624.37$ & 831.52 & 468.25 & 372.81 & 652.06 & 680.15 & 450.64 \\
\hline $\begin{array}{l}\text { Total assets } \\
\text { (PRs mn) }\end{array}$ & $7,996.71$ & $6,707.24$ & $6,459.04$ & $4,039.88$ & $3,747.98$ & $1,714.17$ & $1,292.84$ \\
\hline $\begin{array}{l}\text { PAT/LAT } \\
\text { (PRs mn) }\end{array}$ & -157.80 & -231.10 & -199.57 & -204.85 & -1.75 & -0.24 & -12.89 \\
\hline ROA & -2.1 & -0.6 & -3.3 & -5.1 & -1.8 & -0.2 & -2.5 \\
\hline ROE & -9.7 & -3.7 & -350.1 & -84.2 & -3.3 & 0.5 & -3.2 \\
\hline ROR & -19.7 & -6.7 & -41.1 & -42.4 & -14.2 & -3.5 & -48.4 \\
\hline $\begin{array}{l}\text { Capital } \\
\text { ratio }\end{array}$ & 20.4 & 15.8 & 6.7 & 11.7 & 20.9 & 40.8 & 40.7 \\
\hline $\begin{array}{l}\text { EPS/loss } \\
\text { per share }\end{array}$ & -84.0 & -63.7 & -340.8 & -36.6 & -113.1 & 13.5 & -18.1 \\
\hline ROCE & -8.7 & -2.5 & -15.4 & -36.0 & -3.1 & -0.2 & 4.1 \\
\hline $\begin{array}{l}\text { Asset } \\
\text { turnover } \\
\text { ratio } \\
\text { (times) }\end{array}$ & 0.09 & 0.08 & 0.10 & 0.09 & 0.12 & 0.10 & 0.11 \\
\hline $\begin{array}{l}\text { Current } \\
\text { ratio } \\
\text { (times) }\end{array}$ & 1.05 & 1.16 & 1.0 & 1.03 & 1.08 & 1.01 & 1.4 \\
\hline $\begin{array}{l}\text { Debt to } \\
\text { equity }\end{array}$ & 412.6 & 533.5 & $4,297.5$ & 439.7 & 439.2 & 162.8 & 847.6 \\
\hline $\begin{array}{l}\text { Debt to } \\
\text { assets }\end{array}$ & 79.6 & 84.2 & 93.3 & 88.2 & 79.1 & 59.2 & 201.2 \\
\hline $\begin{array}{l}\text { Operating } \\
\text { profit ratio }\end{array}$ & -27.0 & -133.0 & -57.6 & 3.0 & -23.2 & -5.8 & -53.0 \\
\hline
\end{tabular}

Note: All values given in percent unless otherwise stated. The average value of financial ratios was obtained by computing the ratio for each investment bank over the period 2007-11 (see Appendix).

Source: Authors' calculations. 
Figures 1a-n: Indicators for investment banks (average value for 2007-11)

Total assets (PRs mn)

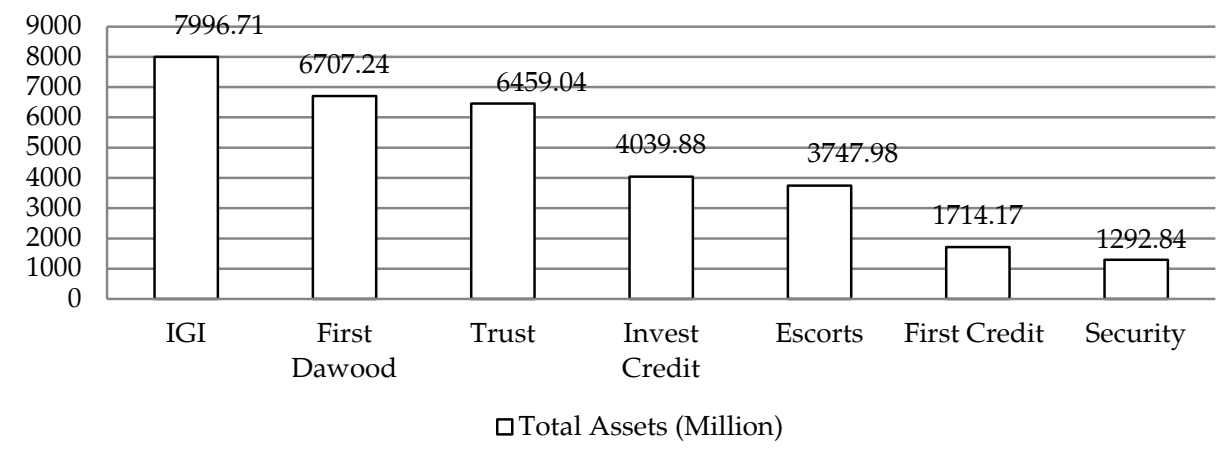

Total equity (PRs mn)
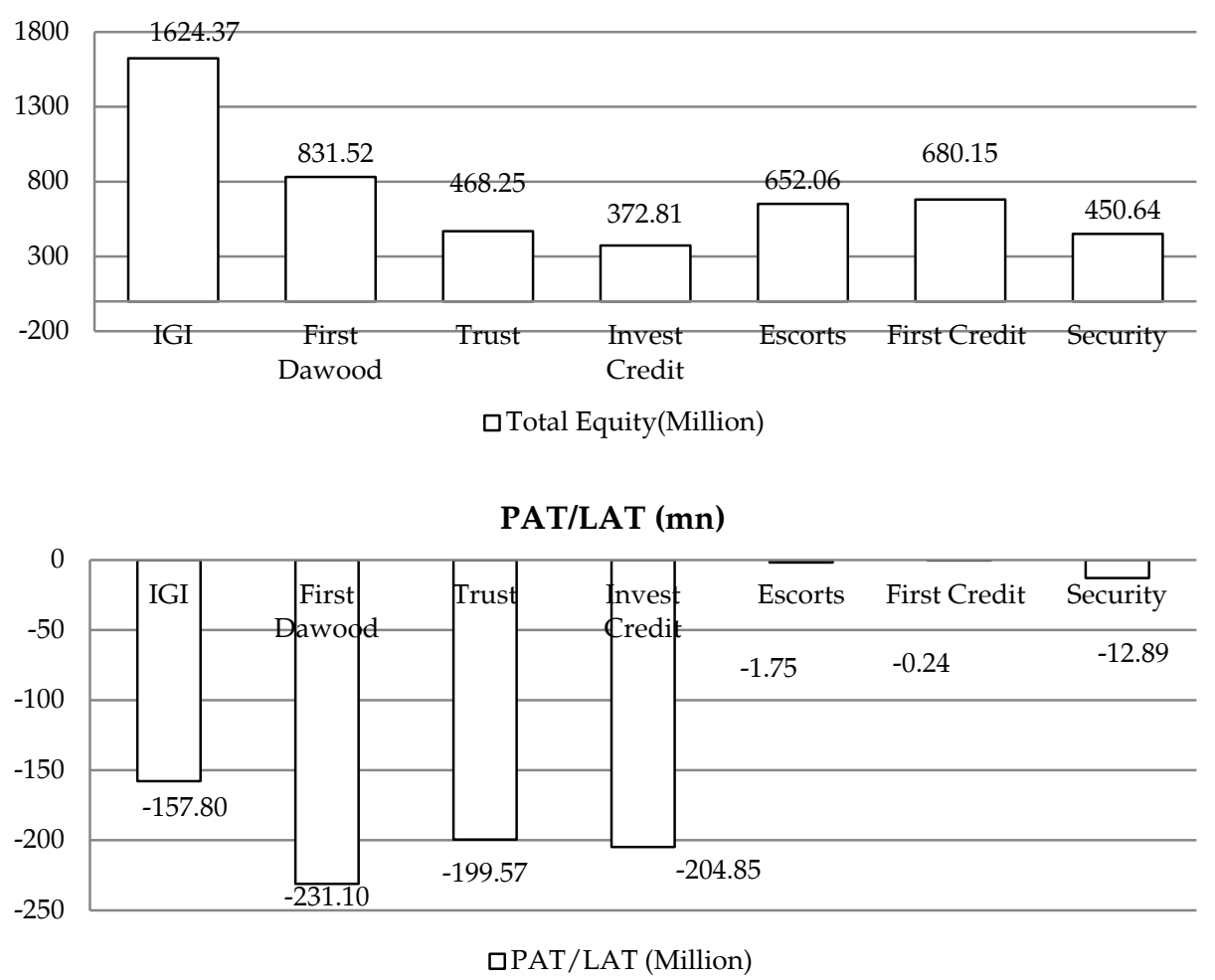

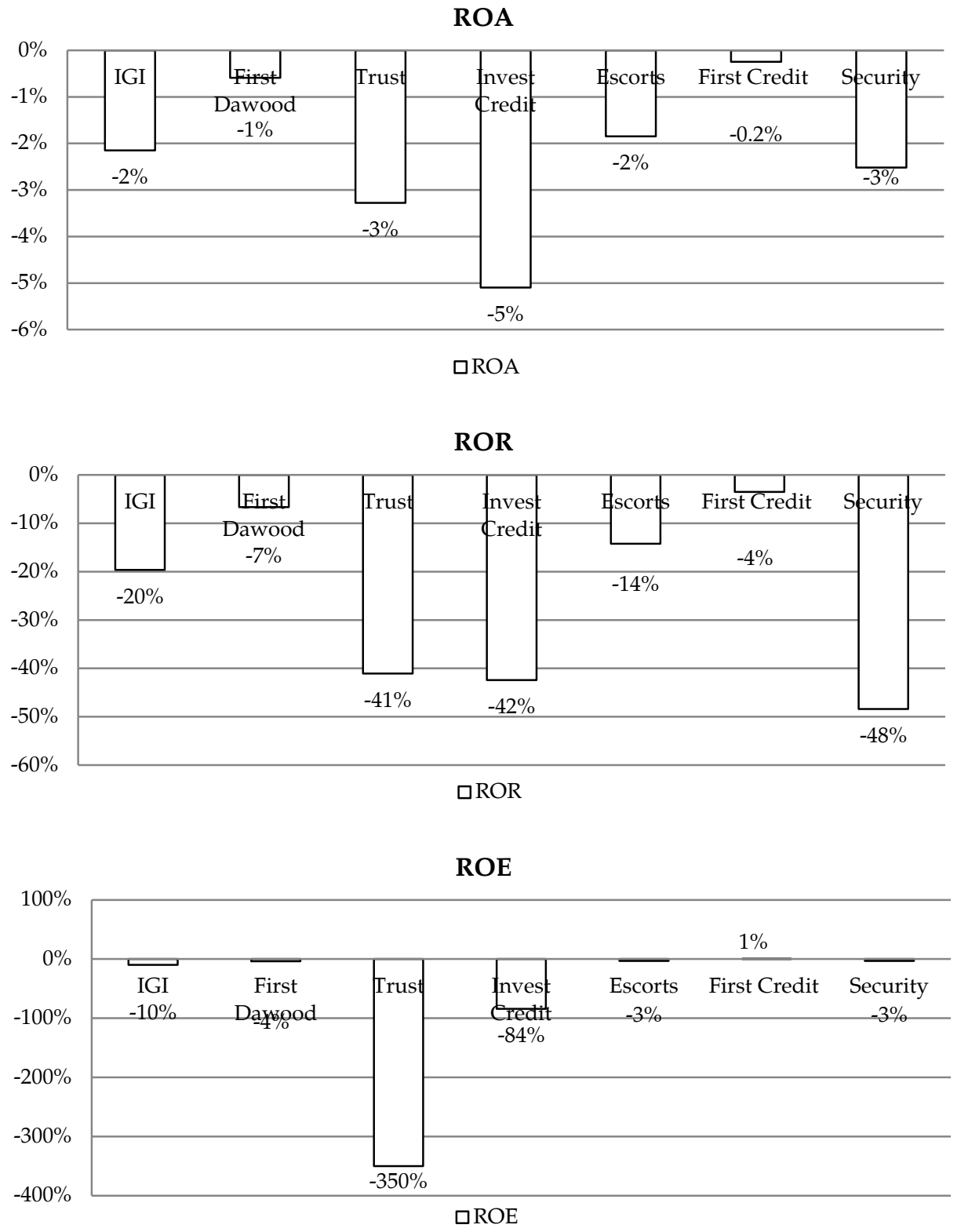


\section{the Current Financial Crisis}
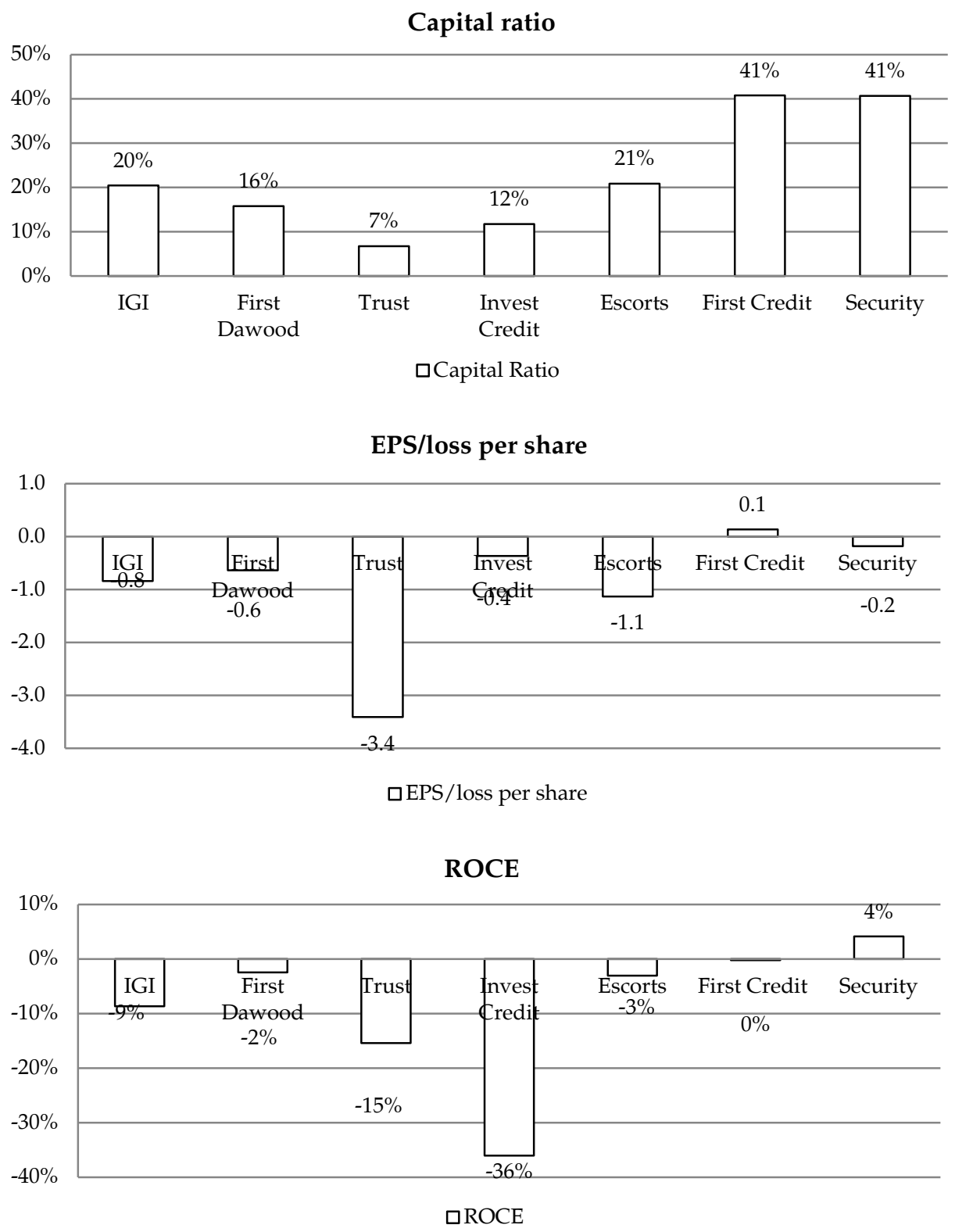

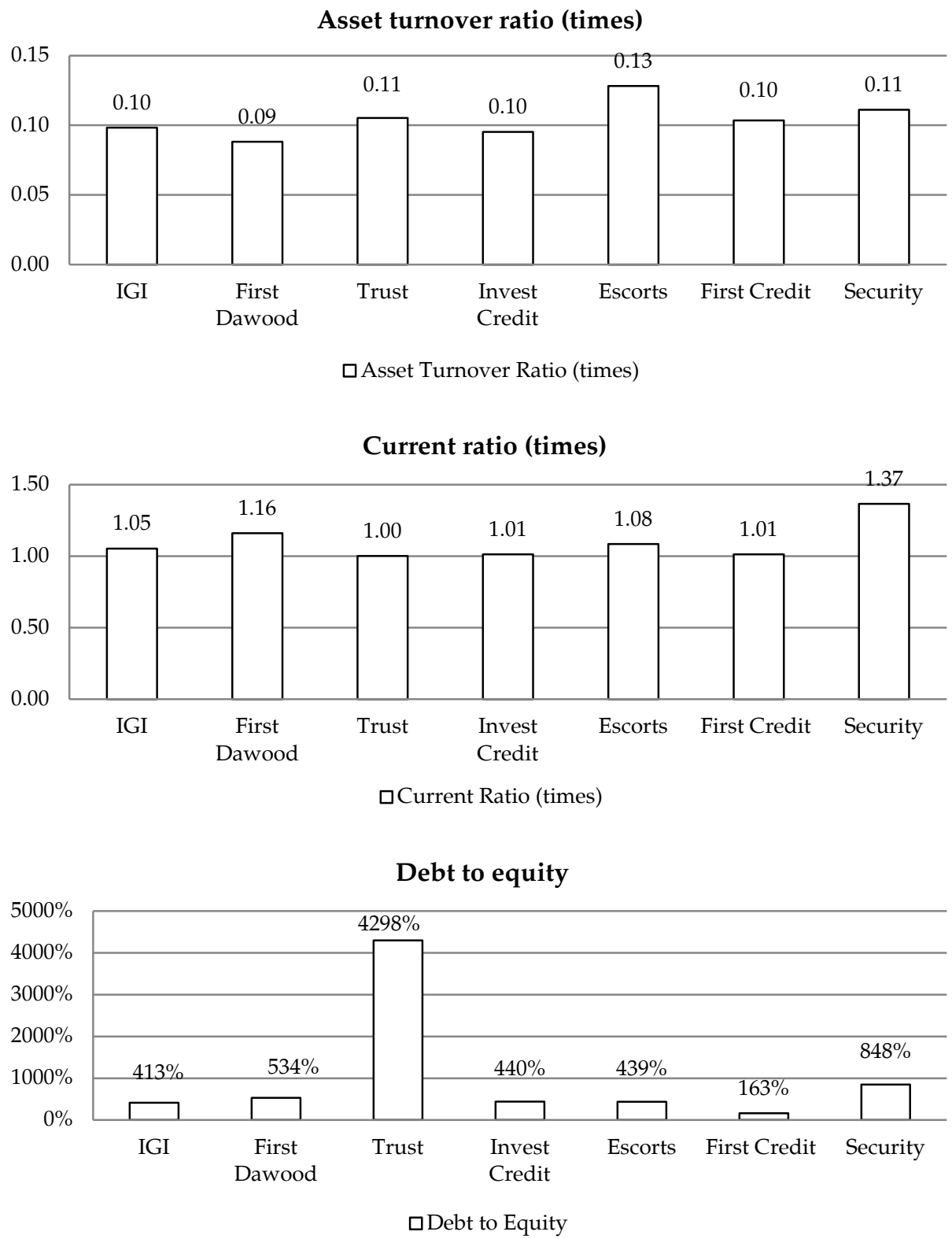

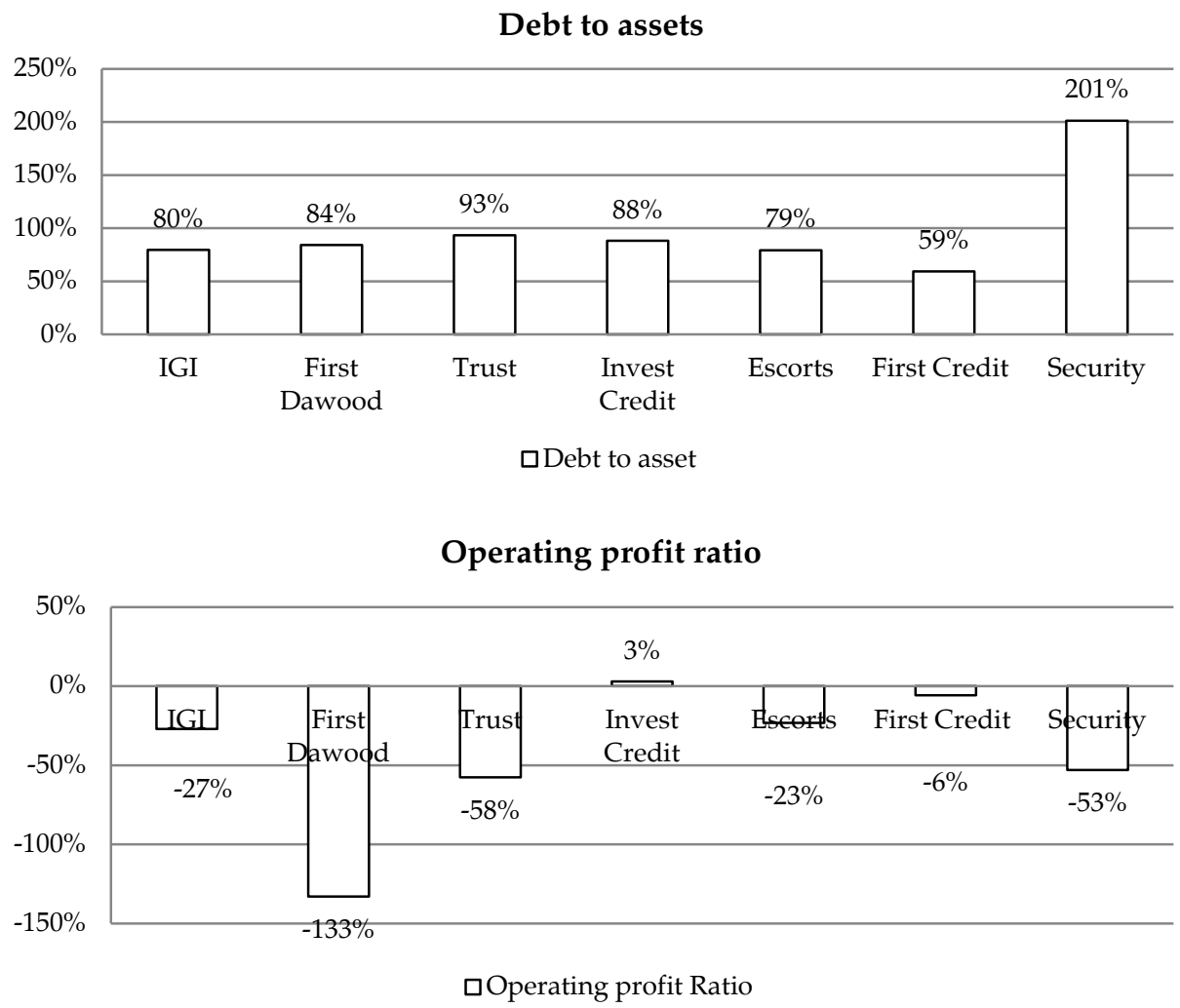

Both the domestic and global economy faced enormous challenges during 2008-11. The period was marked by worsening international recessionary trends, an increase in the tax base, deteriorating law and order (especially in the north), a worsening geopolitical situation, high inflation, a lack of new investment, acute power shortages, and devastating floods. Additionally, the economy faced an increased current account deficit, rapidly shrinking foreign exchange reserves, slow capital flows, and a tight monetary stance. The closure of the country's stock exchanges for over 100 days set a new negative world record and was associated with falling investment, low growth, and rising total debt, all of which had a negative impact on the local economy.

These factors led to a serious liquidity crunch in the country and a wave of defaults spread across the financial sector, increasing nonperforming loans to unprecedented levels. Nonbank financial institutions, which depend on resources borrowed from commercial banks, were deprived of fresh funds and their business cycles disrupted. 
Overall, economic activity in the country was seriously affected during this period, discouraging investors. The pace of business activities slowed down because of the uncertain political and economic situation, while below-expectation macroeconomic figures also kept investors at bay. The financial markets reflected the state of the economy and were unable to sustain their resilience against the uncertainty of the political situation.

\section{Conclusion and Recommendations}

We have examined the financial performance and efficiency of investment banks in Pakistan, using a set of financial ratios for the five-year period 2007-11. The key financial ratios for each bank show that all banks suffered a significant squeeze on profitability during the financial crisis. However, the four larger banks in the sample were affected more than the three smaller banks. Bank size appears to play an important role in performance and efficiency in times of financial crisis. All seven banks maintained a reasonable average current ratio throughout the period, indicating that they were able to meet their financial obligations to creditors.

Our analysis shows that smaller investment banks perform better (in terms of lower losses) during a financial crisis, implying that success does not necessarily depend on economies of scale. We therefore recommend that banks focus on strategies to improve their performance, irrespective of size.

Although the outcomes achieved in this study may be acceptable in light of earlier studies, some limitations still apply. First, we have considered only a five-year period, which might not provide an accurate picture, especially of the pre-crisis period. Second, other variables that could have been incorporated include external factors that have a significant impact on bank performance. Third, the small sample size may have affected the validity of the results. Further studies in this area could extend the present study by comparing its results with financial sector averages and exploring the differences to derive further insight. 


\section{References}

Abreu, M., \& Mendes, V. (2002). Commercial bank interest margins and profitability: Evidence from EU countries (Working Paper No. 245). Porto, Portugal: Universidade do Porto).

Akhtar, M. H. (2002). X-efficiency analysis of commercial banks in Pakistan: A preliminary investigation. Pakistan Development Review, 41(4), 567-580.

Akmal, M., \& Saleem, M. (2008). Technical efficiency of the banking sector in Pakistan. SBP Research Bulletin, 4(1), 61-80.

Al-Hashimi, A. (2007). Determinants of bank spreads in sub-Saharan Africa. Mimeo.

Ali, S. A., Yahya, F., Nauman, M., Raza, M. S., \& Gilani, M. S. (2012). Efficiency and profit analysis of investment banking in Pakistan (2001-2011). Interdisciplinary Journal of Contemporary Research in Business, 4(2), 1067-1087.

Amor-Tapia, B., Tascón, M. T., \& Fanjul, J. L. (2006). Determinants of commercial banks' residual profit: An industry approach (Mimeo). León, Spain: Universidad de León.

Ataullah, A., Cockerill, T., \& Le, H. (2004). Financial liberalization and bank efficiency: A comparative analysis of India and Pakistan. Applied Economics, 36(17), 1915-1924.

Athanasoglou, P. P., Brissimis, S. N., \& Delis, M. D. (2008). Bank-specific, industry-specific and macroeconomic determinants of bank profit. Journal of International Financial Markets, Institutions and Money, 18(2), 121-136.

Athanasoglou, P. P., Delis, M. D., \& Staikouras, C. K. (2006). Determinants of bank profitability in the southeastern European region. Journal of Financial Decision Making, 2(2), 1-17.

Aurangzeb, Z. (2012). Contributions of banking sector in economic growth: A case of Pakistan. Economics and Finance Review, 2(6), 45-54.

Barajas, A., Steiner, R., \& Salazar, N. (1999). Interest spreads in banking in Colombia, 1974-96. IMF Staff Papers, 46(2), 196-224. 
Berger, A. N., \& Humphrey, D. B. (1997). Efficiency of financial institutions: International survey and directions for future research. European Journal of Operational Research, 98(2), 175-212.

Bikker, J. A., \& Hu, H. (2002). Cyclical patterns in profits, provisioning and lending of banks and procyclicality of the new Basel capital requirements. Banca Nazionale del Lavoro Quarterly Review, 55(221), 143-175.

Bourke, P. (1989). Concentration and other determinants of bank profitability in Europe, North America and Australia. Journal of Banking and Finance, 13, 65-79.

Burki, A. A., \& Niazi, G. S. K. (2003, November). The effects of privatization, competition and regulation on banking efficiency in Pakistan, 19912000. Paper presented at the CRC Conference on Regulatory Impact Assessment: Strengthening Regulation Policy and Practice, University of Manchester, UK.

Demirgüç-Kunt, A., \& Huizinga, H. (2000). Financial structure and bank profitability (Policy Research Working Paper No. 2430). Washington, DC: World Bank.

Gul, S., Irshad, F., \& Zaman, K. (2011). Factors affecting bank profitability in Pakistan. Romanian Economic Journal, 39, 61-87.

Hasan, I. (2008). Building trust in investment banking. Address to the PAF Karachi Institute of Economics and Technology. Retrieved from http://www.sbp.org.pk/sbp_bsc/speech/Investment_Banking.pdf

Hassan, M. K., \& Bashir, A. M. (2003, December). Determinants of Islamic banking profitability. Paper presented at the 10th Annual Conference of the Economic Research Forum, Marrakesh, Morocco.

Ho, C.-T., \& Wu, Y. S. (2006). Benchmarking performance indicators for banks. Benchmarking, 13(1/2), 147-159.

Javaid, S., Anwar, J., Zaman, K., \& Gafoor, A. (2011). Determinants of bank profitability in Pakistan: Internal factor analysis. Mediterranean Journal of Social Sciences, 2(1), 59-78.

Khawaja, M., \& Din, M. (2007). Determinants of interest spread in Pakistan. Pakistan Development Review, 46(2), 129-143. 
Kwan, S. H. (2003). Operating performance of banks among Asian economies: An international and time series comparison. Journal of Banking and Finance, 27, 471-489.

Mallik, G., \& Chowdhury, A. (2001). Inflation and economic growth: Evidence from four South Asian countries. Asia-Pacific Development Journal, 8(1), 123-135.

Molyneux, P., \& Thornton, J. (1992). Determinants of European bank profitability. Journal of Banking and Finance, 16, 1173-1178.

Naceur, S. B. (2003). The determinants of the Tunisian banking industry profitability: Panel evidence (Working paper). Tunis, Tunisia: Université Libre de Tunis.

Nasir, S., \& Khalid, M. (2004). Saving-investment behavior in Pakistan: An empirical investigation. Pakistan Development Review, 43(4), 665-682.

Rashid, M. Z. A., Sambasivan, M., \& Johari, J. (2003). The influence of corporate culture and organizational commitment on performance. Journal of Management Development, 22(8), 708-728

Raza, A., Farhan, M., \& Akram, M. (2011). A comparison of financial performance in investment banking sector in Pakistan. International Journal of Business and Social Science, 2(9), 72-82.

Rehman, W., Fatima, G., \& Ahmad, W. (2011). An empirical analysis of financial reforms in Pakistan: Does it affect economic growth? International Journal of Trade, Economics and Finance, 2(4), 341-345.

Rehman, R., \& Raoof, A. (2010). Efficiencies of Pakistani banking sector: A comparative study. International Research Journal of Finance and Economics, 46, 110-128.

Rizvi, S. F. A. (2001). Post-liberalization efficiency and productivity of the banking sector in Pakistan. Pakistan Development Review, 40(4), 605-632.

Short, B. K. (1979). The relation between commercial bank profit rates and banking concentration in Canada, Western Europe and Japan. Journal of Banking and Finance, 3, 209-219. 
Sørensen, B. J. (2002). The strength of corporate culture and the reliability of firm performance. Administrative Science Quarterly, 47(1), 70-91.

Staikouras, C., \& Wood, G. (2003, June). The determinants of bank profitability in Europe. Paper presented at the European Applied Business Research Conference, Venice, Italy.

State Bank of Pakistan. (2011). Financial statement analysis of financial sector (2007-2011). Karachi, Pakistan: Author. Retrieved from http://www.sbp.org.pk/departments/stats/FSA-2007-11.pdf

Vong, P. I., \& Chan, H. S. (2006, June). Determinants of bank profitability in Macau. Paper presented at the 30th Anniversary Conference of the Journal of Banking and Finance, Beijing, China. 


\section{Appendix}

\section{List of investment banks in Pakistan}

\begin{tabular}{llc}
\hline No. & \multicolumn{1}{c}{ Name of investment bank } & KSE \\
\hline 1 & Dawood Investment Bank Ltd & Listed \\
2 & First Credit Investment Bank & Listed \\
3 & Al-towfeek Investment Bank Ltd & \\
4 & Ammar Investment Bank Ltd & \\
5 & Asset Investment Bank & \\
6 & Atlas Investment Bank Ltd & Listed \\
7 & Crescent Investment Bank Ltd & \\
8 & Escorts Investment Bank Ltd & \\
9 & Fidelity Investment Bank Ltd & Listed \\
10 & First International Investment Bank Ltd & Listed \\
11 & Franklin Investment Bank Ltd & \\
12 & IGI Investment Bank Ltd & Listed \\
13 & Invest Capital Investment Bank Ltd & \\
14 & Islamic Investment Bank Limited & \\
15 & Jehangir Siddiqui Investment & Listed \\
16 & National Investment Trust Ltd & Listed \\
17 & Orix Investment Bank Ltd & Listed \\
18 & Prudential Investment Bank & \\
19 & Security Investment Bank & \\
20 & Trust Investment Bank & \\
\hline
\end{tabular}

Source: http:/ /www.globalbankingandfinance.com/Resources/List-Of-Investment-Banks-InPakistan.html

\section{KSE-listed investment banks in Pakistan}

\begin{tabular}{lll}
\hline No. & \multicolumn{1}{c}{ Name of listed investment bank } & \multicolumn{1}{c}{ Total assets } \\
\hline 1 & Dawood Investment Bank Ltd & $148,239,234$ \\
2 & First Credit Investment Bank & $1,517,876,632$ \\
3 & Escorts Investment Bank Ltd & $2,364,875,518$ \\
4 & IGI Investment Bank Ltd & $9,314,957,000$ \\
5 & Invest Capital Investment Bank Ltd & $358,3982,000$ \\
6 & Jehangir Siddiqui Investment & $5,175,200 \mathrm{a}$ \\
7 & Prudential Investment Bank & Not available \\
8 & Security Investment Bank & $940,103,374$ \\
9 & Trust Investment Bank & $5,380,636,427$ \\
\hline
\end{tabular}

Note: $\mathrm{a}=$ value obtained from 2006 annual report. 
Financial analysis of investment banks in Pakistan

\begin{tabular}{|c|c|c|c|c|c|c|}
\hline Ratio & 2007 & 2008 & 2009 & 2010 & 2011 & Average \\
\hline \multicolumn{7}{|l|}{ Dawood Investment Bank } \\
\hline Total equity (PRs mn) & $1,685.5$ & $1,779.0$ & -518.7 & 620.7 & 591.1 & 831.5 \\
\hline Total assets (PRs mn) & $12,362.6$ & $11,064.2$ & $5,136.4$ & $3,148.1$ & $1,824.9$ & $6,707.2$ \\
\hline PAT/LAT (mn) & 188.5 & 113.7 & $-1,791.4$ & 377.7 & -44.0 & -231.1 \\
\hline $\mathrm{ROA}$ & 2 & 1.0 & -35 & 12 & -2 & -0.6 \\
\hline ROE & 11 & 6.4 & 345 & 61 & -7 & -3.7 \\
\hline ROR & 15 & 8 & -762 & 129 & -23 & -6.7 \\
\hline Capital ratio & 14 & 16 & -10 & 20 & 32 & 0.16 \\
\hline EPS/loss per share & 3.31 & 2.00 & -28.59 & 6.03 & -0.33 & -63.7 \\
\hline ROCE & 5 & 1 & -227 & 13 & 1 & -2.5 \\
\hline Asset turnover ratio (times) & 0.10 & 0.13 & 0.05 & 0.09 & 0.11 & 0.09 \\
\hline Current ratio (times) & 1.11 & 1.22 & 0.79 & 1.75 & 1.98 & 1.16 \\
\hline Debt to equity & 633 & 522 & -1090 & 407 & 209 & 533.5 \\
\hline Debt to assets & 86 & 84 & 110 & 80 & 68 & 84.2 \\
\hline Operating profit & 14 & 2 & -768 & 80 & 7 & -133 \\
\hline \multicolumn{7}{|l|}{ First Credit Investment Bank } \\
\hline Total equity (PRs mn) & 547.5 & 550.2 & 786.2 & 801.5 & 715.4 & 680.1 \\
\hline Total assets (PRs mn) & $2,058.5$ & $1,729.3$ & $1,800.5$ & $1,464.7$ & $1,517.9$ & $1,714.2$ \\
\hline PAT/LAT (mn) & 55.7 & 16.0 & 7.7 & 7.9 & -88.5 & -0.2 \\
\hline ROA & 3 & 1 & 0.4 & 1 & -6 & -0.2 \\
\hline ROE & 10 & 3 & 1 & 1 & -12 & 0.5 \\
\hline ROR & 29 & 9 & 4 & 5 & -64 & -3.5 \\
\hline Capital ratio & 27 & 32 & 44 & 55 & 47 & 40.8 \\
\hline EPS/loss per share & 1.39 & 0.40 & 0.12 & 0.12 & -1.36 & 13.5 \\
\hline ROCE & 8 & 4 & 2 & 1 & -15 & -0.2 \\
\hline Asset turnover ratio (times) & 0.09 & 0.10 & 0.12 & 0.11 & 0.09 & 0.10 \\
\hline Current ratio (times) & 0.98 & 0.92 & 0.82 & 1.17 & 1.18 & 1.01 \\
\hline Debt to equity & 276 & 214 & 129 & 83 & 112 & 162.8 \\
\hline Debt to assets & 73 & 68 & 56 & 45 & 53 & 59.2 \\
\hline Operating profit & 30 & 14 & 6 & 20 & -99 & -5.8 \\
\hline \multicolumn{7}{|l|}{ Escorts Investment Bank Limited } \\
\hline Total equity (PRs mn) & 798.1 & 848.3 & 604.7 & 524.8 & 484.4 & 652.1 \\
\hline Total assets (PRs mn) & $5,934.7$ & $6,496.9$ & $2,107.6$ & $1,825.0$ & $2,375.7$ & $3,748.0$ \\
\hline PAT/LAT (mn) & 130.2 & 137.8 & -166.2 & -79.4 & -31.1 & -1.8 \\
\hline $\mathrm{ROA}$ & 2 & 2 & -8 & -4 & -1 & -2 \\
\hline ROE & 16 & 16 & -27 & -15 & -6 & -3 \\
\hline ROR & 15 & 16 & -47 & -44 & -13 & -14 \\
\hline
\end{tabular}



the Current Financial Crisis

\begin{tabular}{|c|c|c|c|c|c|c|}
\hline Ratio & 2007 & 2008 & 2009 & 2010 & 2011 & Average \\
\hline Capital ratio & 13 & 13 & 29 & 29 & 20 & 21 \\
\hline EPS/loss per share & 0.31 & 0.31 & -3.77 & -1.80 & -0.70 & -113 \\
\hline ROCE & 8 & 5 & -15 & -8 & -6 & -3 \\
\hline Asset turnover ratio (times) & 0.14 & 0.13 & 0.17 & 0.10 & 0.10 & 0.13 \\
\hline Current ratio (times) & 1.20 & 1.14 & 1.14 & 0.97 & 0.97 & 1.08 \\
\hline Debt to equity & 644 & 666 & 249 & 248 & 390 & 439 \\
\hline Debt to assets & 87 & 87 & 71 & 71 & 80 & 79 \\
\hline Operating profit & 17 & 9 & -83 & -45 & -14 & -23 \\
\hline \multicolumn{7}{|l|}{ IGI Investment Bank Limited } \\
\hline Total equity (PRs mn) & $1,049.6$ & $2,182.2$ & $1,867.5$ & $1,604.9$ & $1,417.7$ & $1,624.4$ \\
\hline Total assets (PRs mn) & $6,649.0$ & $9,831.4$ & $6,548.7$ & $8,233.4$ & $8,721.1$ & $7,996.7$ \\
\hline PAT/LAT (mn) & -39.2 & -6.4 & -375.1 & -199.4 & -169.0 & -157.8 \\
\hline ROA & -1 & -0.1 & -6 & -2 & -2 & -2.15 \\
\hline ROE & -4 & -0.3 & -20 & -12 & -12 & -9.69 \\
\hline ROR & -7 & -1 & -49 & -24 & -18 & -19.65 \\
\hline Capital ratio & 16 & 22 & 29 & 19 & 16 & 20.45 \\
\hline EPS/loss per share & -0.64 & -0.06 & -1.77 & -0.94 & -0.80 & -0.84 \\
\hline ROCE & -2 & -1 & -18 & -17 & -5 & -8.68 \\
\hline Asset turnover ratio (times) & 0.09 & 0.08 & 0.12 & 0.10 & 0.11 & 0.10 \\
\hline Current ratio (times) & 1.16 & 1.13 & 1.01 & 0.96 & 1.01 & 1.05 \\
\hline Debt to equity & 534 & 351 & 251 & 413 & 515 & 413 \\
\hline Debt to assets & 84 & 78 & 71 & 81 & 84 & 80 \\
\hline Operating profit & -14 & -6 & -59 & -46 & -10 & -27 \\
\hline \multicolumn{7}{|c|}{ Invest Capital Investment Bank Limited } \\
\hline Total equity (PRs mn) & 432.8 & 570.7 & 998.6 & 234.0 & -372.0 & 372.8 \\
\hline Total assets (PRs mn) & $1,859.6$ & $2,028.2$ & $7,847.0$ & $4,880.5$ & $3,584.0$ & $4,039.9$ \\
\hline PAT/LAT (mn) & 17.9 & -19.5 & 165.4 & -748.9 & -439.1 & -204.8 \\
\hline ROA & 1 & -1 & 2 & -15 & -12 & -5 \\
\hline ROE & 4 & -3 & 17 & -320 & -118 & -84 \\
\hline ROR & 8 & -7 & 114 & -116 & -212 & -42 \\
\hline Capital ratio & 23 & 28 & 13 & 5 & -10 & 12 \\
\hline EPS/loss per share & 0.51 & -0.08 & 1.91 & -2.63 & -1.54 & -37 \\
\hline ROCE & 8 & -1 & 6 & -60 & -134 & -36 \\
\hline Asset turnover ratio (times) & 0.12 & 0.15 & 0.02 & 0.13 & 0.06 & 0.10 \\
\hline Current ratio (times) & 1.13 & 1.13 & 1.02 & 0.94 & 0.84 & 1.01 \\
\hline Debt to equity & 330 & 255 & 686 & 1,986 & $-1,058$ & 440 \\
\hline Debt to assets & 77 & 72 & 87 & 95 & 110 & 88 \\
\hline Operating profit & 15 & -2 & 121 & -109 & -10 & 3 \\
\hline
\end{tabular}

Security Investment Bank 


\begin{tabular}{|c|c|c|c|c|c|c|}
\hline Ratio & 2007 & 2008 & 2009 & 2010 & 2011 & Average \\
\hline Total equity (PRs mn) & 592.6 & 304.4 & 450.7 & 452.5 & 453.0 & 450.6 \\
\hline Total assets (PRs mn) & $2,802.1$ & 931.5 & 959.5 & 835.6 & 935.5 & $1,292.8$ \\
\hline PAT/LAT (mn) & 89.2 & 26.6 & -192.7 & 9.8 & 2.6 & -12.9 \\
\hline ROA & 3 & 3 & -20 & 1 & 0.3 & -2.52 \\
\hline ROE & 15 & 9 & -43 & 2 & 1 & -3.24 \\
\hline ROR & 28 & 14 & -300 & 12 & 4 & -48.39 \\
\hline Capital ratio & 21 & 33 & 47 & 54 & 48 & 40.67 \\
\hline EPS/loss per share & 2.08 & 0.52 & -3.75 & 0.19 & 0.05 & -0.18 \\
\hline ROCE & 16 & 9 & -5 & 1 & 0 & 4 \\
\hline Asset turnover ratio (times) & 0.11 & 0.21 & 0.07 & 0.10 & 0.07 & 0.11 \\
\hline Current ratio (times) & 1.18 & 1.13 & 1.47 & 1.58 & 1.47 & 1.37 \\
\hline Debt to equity & 3,728 & 206 & 113 & 85 & 107 & 848 \\
\hline Debt to assets & 788 & 67 & 53 & 46 & 52 & 201 \\
\hline Operating profit & 31 & 14 & -315 & 4 & 1 & -53 \\
\hline \multicolumn{7}{|l|}{ Trust Investment Bank } \\
\hline Total equity (PRs mn) & $1,022.7$ & 982.6 & 160.1 & 48.1 & 127.8 & 468.2 \\
\hline Total assets (PRs mn) & $6,443.7$ & $8,089.4$ & $6,475.3$ & $5,906.2$ & $5,380.6$ & $6,459.0$ \\
\hline PAT/LAT (mn) & 103.0 & 149.8 & -715.2 & -701.8 & 166.4 & -199.6 \\
\hline ROA & 2 & 2 & -11 & -12 & 3 & -3 \\
\hline ROE & 10 & 15 & -447 & $-1,459$ & 130 & -350 \\
\hline ROR & 14 & 16 & -107 & -156 & 27 & -41 \\
\hline Capital ratio & 16 & 12 & 2 & 1 & 2 & 7 \\
\hline EPS/loss per share & 1.76 & 2.56 & -12.22 & -11.99 & 2.84 & -341 \\
\hline ROCE & 3 & 2 & -44 & -49 & 10 & -15 \\
\hline Asset turnover ratio (times) & 0.11 & 0.12 & 0.10 & 0.08 & 0.11 & 0.11 \\
\hline Current ratio (times) & 1.15 & 0.91 & 0.95 & 0.94 & 1.06 & 1.00 \\
\hline Debt to equity & 530 & 723 & 3,944 & 12,180 & 4,109 & 4,298 \\
\hline Debt to assets & 84 & 88 & 98 & 99 & 98 & 93 \\
\hline Operating profit & 16 & 7 & -141 & -200 & 30 & -58 \\
\hline
\end{tabular}

Note: All values given in percent unless otherwise stated.

Source: Authors' calculations. 